will be increased to approximately 100.

Reporting for the Position Paper Committee, Dr. Henderson noted that the draft on the HIVinfected healthcare worker was coming to completion. Dr. Mayhall also noted that groups are working currently on a hazardous waste report and a surgical wound surveillance report.

The Board discussed in detail an issue raised by Dr. Jeffrey Band concerning PRO and Health Care Financing Administration (HFCA) use of nosocomial infections as a generic quality screen. Board members were assigned to review this issue with HFCA. SHEA members who have had specific problems with overzealous use of nosocomial infections as quality monitors, should contact the SHEA secretary, Dr. William Mar-tone.

The next meeting of the SHEA Board will be in October during the Interscience Conference on Antimicrobial Agents and Chemotherapy.

\section{ASM-Division L}

The Nosocomial Infections Division (Division L) of the American Society for Microbiology has 522 members according to the 1989 Annual Report, issued July 1990. This represents an $18 \%$ growth in the Division L membership; an $8 \%$ growth was noted in the report for overall ASM membership. The current Division L officers are William R. Jarvis, Chair and Brian P. Simmons, Chair-elect. The Division L representative to the ASM council is Bruce Hamory. This year's annual ASM meeting will be held May 5-9, 1991, in Dallas, Texas.

\section{International Congress on Sepsis}

The Second International Congress on Immune Consequence of
Trauma, Shock, and Sepsis: Mechanisms and Therapeutic Approaches will be held March 6-9, 1991 in Munich, West Germany.

This congress will provide a multidisciplinary look at basic and clinical research into these issues. Components of the host defense system will be reviewed and insights into the onset and sequence of cellular events surrounding the septic syndrome will be detailed. There will be a number of topics of interest to infection control physicians including bacterial translocation, interactions of host defense in healing, modification of the inflammatory response, and various aspects of the complex theme of immunoenhancement as a therapeutic strategy.

Individuals wishing to obtain abstract forms or conference registration materials should write Congress Organization AfF, Handelstrasse 1, 8000 Munchen 80, West Germany.

Brief items of interest for the SHEA Newsletter may be sent to Robert A. Weinstein, MD, SHEA Newsletter Editor, Division of Infectious Diseases, Michael Reese Hospital, Lake Shore Drive at 31st St., Chicago, IL 60616. Copy must be typed, doublespaced and may not exceed five pages.

\title{
Membership Application Inquiry:
}

\begin{tabular}{l} 
Mail to: Secretary \\
Society of Hospital \\
Epidemiologists of America \\
c/o Slack, Incorporated \\
6900 Grove Road \\
Thorofare, NJ 08086 \\
NAME: $\frac{\text { CURRE POSITION: }}{\text { ADDRESS: }}$ \\
\hline $\begin{array}{l}\text { Doctoral Degree _ MD _ } \mathrm{MhD} \\
\text { Date and University: }\end{array}$
\end{tabular}

Specify work in hospital epidemiology and related fields:

Dates in this position:

Related work in the field:

) Check type of membership application:

Active Membership

(Calendar year dues \$75)

Associate Membership

(Calendar year dues $(\$ 35)$ 